\title{
An Assessment of New Factors Which Will Decide the Future of Dental Practice
}

\author{
by \\ James M. DYCE* and J. Alastair DOW*
}

The purpose of this paper is to gain some perspective on the future setting in which we and our immediate successors will practice and to study some of the forces which are operative in this field.

A paper of this length can do no more than outline what is going on in our profession and give some of the evidence we have so far found concerning the factors which are deciding the future.

We need to do some hard thinking on this subject of dentistry in the Soviet Union and ideas behind the revolutionary changes there and our response to them, whether we like it or not, because one of the new factors which dominates and controls dental practice in nearly half of the whole human family is the Soviet system of training, practice and philosophy.

There is a story told of a hen-run which was situated near to a Rugby field. On one occasion the Rugby ball was kicked over the wire into the hen-run. When the cock saw the Rugby ball lying there, he walked round it and then he called all the hens together and he said, “Now girls, I don't want to complain, but just take a look at what some other firms are producing."

Any responsible attempt to look into the future will of necessity include a study of the Soviet system and the dynamic idea which gives it such momentum.

There are three major features about the Soviet which we wish to deal with, arising from the above, and we wish to deal quite briefly with each.

First - the creation of a new framework for the dental profession.

Second - the fact that the dentist is faced with a continuing choice of loyalty.

Third - the intense programme of indoctrination in Marxist-Leninist ideology.

\section{The Creation of a New Framework for the Dental Profession}

Soviet dental history recounts that around 1700 Peter the First used to practice dentistry. In 1710 the first official dentist set up in Russia, and he was a Frenchman. One hundred years later there had been formed a Russian Medical List and there were twenty-four dentists. Still a hundred years later, in 1911, came the first moves to try to incorporate dentistry in medicine.

Within half-a-year of the Bolshevik Revolution in 1917, the Soviet regime set

The present paper, published here with a few changes for publicational purposes, was read before a meeting held at the Royal College of Surgeons, London, February 1962.

* Dr. Dyce, L. R. C. P., L. D.S., D. D.S., serves as President of the American Dental Society of London and Dr. Dow has L. D. S., D. D.S. 
up its own central medical organisation, completely sutordinate to itself, headed by trusted members of the Communist Party. Eighteen years later, in 1935, the system of stomatology as a medical discipline was introduced to replace dentistry as it had been, with the founding of the first Institute of Stomatology. The stomatologists, who have a full medical qualification and specialise in dentistry, consider themselves as physicians rather than as dentists. Most of the material in this paper covers all branches of the medical profession, including dentists.

Like all other medical schools in Russia, the Institute of Stomatology is under the Ministry of Health and not a university faculty. In the last twenty-five years 16,000 stomatologists have been produced and during the same pericd the number of dentists has risen from 20,000 to 29,000 - an increase of 9,000. This indicates a definite trend to train stomatologists rather than dentists. The dentist can become a stomatologist by working an extra three years, possibly through correspondence, and receiving clinical training for one year and half to acquire the diploma of a stomatologist.

Added to this sweeping change in the structure of the training of the physiciandentist is a change in graduate output. In 1956 there were only twelve Stomatological Institutes, enrolling 800 students a year. By 1960 there were 26 Institutes. The senior stomatologist of the Ministry of Health, Dr. Rudko, says, "In the very near future our country will be producing every year more than 5,500 young stomatologists and dentists and the total number of specialists will be brought up to a proportion of one to every 2,000 or 3,000 persons".

It is also interesting to note that an important part in the establishment of stomatology in China is being played by the stomatologists trained at the Moscow Medical Stomatological Institute.

The Ministry of Health, besides training the profession and organising the health service, also publishes the principal dental journal called "Stomatology" which is issued six times per year. A review of the past two years' journals shows certain features. There is little discussion on the commoner aspects of minor oral surgery (impactions, cysts, retained roots, etc.). Surgical sections are given over to, in the main, treatment of congenital lip-palatal defects, removal and treatment of various carcinomata, facial fractures and certain plastic procedures. There is some interest in the aetiology of caries and various studies of stomatological disease in different areas mainly industrial, but no reference is made to fluoridation. Only two articles (and those short) on orthodontic problems and one on the air-turbine. These appear rather elementary. Little is written concerning crown and bridge prosthesis. Only one article discusses the uses and properties of certain gold alloys. No new methods of anaesthesia are published. One article discusses the organisation of the profession in Great Britain. Almost no advertisements appear, but of the few a British firm several times occupies the complete back page of the cover.

The recent increase in size of the magazine by 32 pages was naturally in conjunction with an increase in the number of articles. The ratio between the types, however, was similar - with the exception of those on organisation and history, which increased much more than the others and were put into a much more prominent place in the journal.

In the six issues of 1961 there were 53 articles on therapeutics, 66 on surgery, 34 on prosthetics, 17 on organisation and history and 54 on clinical notes. 


\section{Hours, Conditions and Organisation}

As far as can be gathered from the information available, it seems that the dentist works a five-and-a-half hour day, six days per week - a total of thirty-three hours. His salary for this as a new graduate is about $£ 33$ per month. In ten years it will rise by $17 \%$ and $20 \%$ to about $£ 46$ per month. The dentist will earn $25 \%$ less than the stomatologist.

The health service, which is free to all, is designed to increase the productivity of the worker, in the interests of the monolithic state. During the twenty-seven years of their Sovietised existence, the dentists have had no national organisation other than the trade union to which all health personnel belong, be he consultant or ambulance driver. Two years ago an all-union medical scientific society of stomatologists was established. It is said that only stomatologists are admitted, that there are about 50 members and that its purpose is entirely scientific and professional and not social or economic.

The best way of describing the necessity of joining the Health Workers Union is to illustrate what happens if you do not. The following statement was made to one of the authors in West Berlin by a dentist who had recently crossed from the East. "Yes, the ground goes from under your feet. There is no pressure, but you find you cannot have this or that; the union members get their supplies first. Your children can't go to school, because you are not holding a union card. You can't go on holiday, because the resorts are booked up by the unions and you are not a member. You might do what you liked, if you had money. If you want some, you have to fake bills to get some out of the bank. If you don't work you don't live, and not many want to practice dentistry between the ages of 80 and 90 as has happened. If you are cross with your maid, you may find she will betray you to the secret police."

The Medical Workers Union has a journal which comes out twice a week, called "The Medical Worker". Its function is to instruct and direct the profession in Marxism-Leninism.

\section{The Problem of Loyalty in Dental Profession}

Dr. Harold Hillenbrand of American Dental Association sums up the situation this way :

"Because of the nature of the Soviet State, the dentist and all health profession personnel necessarily face the ultimate choice of primary service to the needs of the patient or to the needs of the State. To confront health profession personnel with such a choice is to negate the primary objective of the professional man or woman, which is to place the service to the patient above all other things. Soviet philosophy, by necessity, therefore, confounds and conflicts with the philosophy of primary service to human beings which has illuminated professions everywhere from time immemorial."

It was Stalin himself who declared that the training of specialists in one particular branch of science was not sufficient. Speaking of the fact that a Leninist cannot be just a specialist in his favourite science, he added, "There is one branch of science which Bolsheviks in all branches of science are in duty bound to know, and that is the Marxist-Leninist science of society".

Stalin also made it clear that when selecting professional personnel the primary 
concern should be ideological reliability. The future specialist comes under the eye of the Government in an editorial in "Pravda" a few days ago, in which it is stated that the most important factor in the ideological and political work of higher educational establishments is teaching " a world outlook to understand the process and perspective of world development and to correctly analyse events which occur in our country and beyond its borders". And as part of this the embryo student is conscripted to work in industry or on a state or collective farm for two years between leaving school and starting his medical study.

Perhaps the best illustration of the problems of loyalties faced in medical education was the following case reported by an interviewed physician who said:

"I was asked by a professor who was sick to substitute at an examination. I always tried to ask the students the most elementary questions, rather than details which they would anyway acquire later on. There was one student, and he was very weak. I did not know at the time that he was a Party member. I gave him a three out of a possible maximum of five, which was not failing, but not good either - just passing. I saw that the other professor on the examining board was quite upset and he told me in a low voice, 'You see, you asked the best student, he always gets excellent grades. A three will spoil the entire record. $\mathrm{He}$ is a komsomol and a representative of the Party. What do you think can be done about it?' "The physician told the professor that if he wanted, he could re-examine him again, then he left. The student was re-examined. He received a grade of five, and his record was not marred. "I feel", added the doctor, "that he knew less than he should have known, but his Party membership helped him pass the subject".

As far as the practitioner is concerned, the conflict of loyalties may be illustrated by the fact that a physician must not issue a sickness certificate unless the patient has a temperature, and the height of this temperature varies with the urgency of the industrial situation and requirements of the labour force. Only a limited number of sickness certificates may be granted in any one period, and questions are asked and medical histories may have to be produced if this quota is exceeded.

The professional actions of the Soviet physician are dictated by the bureaucratic organisation that employs him, through directives and instructions he receives from his superiors. These directions have, to a large extent, superseded the code of ethics that direct the professional conduct of the physician in private practice. It is perhaps significant to note that the Hippocratic Oath, which was taken by the Czarist doctors and which we still accept in the West, was abolished after the Revolution because it symbolised bourgeois medicine and was considered incompatible with the spirit of Soviet medicine. One writer in "The Medical Worker" puts it, thus "If the prerevolutionary physician was proud of the fact that for him medicine and nothing else existed, the Soviet doctor, on the other hand, is proud of the fact that he actively participates in the building of Socialism".

\section{Indoctrination of the Profession in Marxism-Leninism}

Substantively, there is little that differentiates or could differentiate Soviet from Western medical training, except for one important and outstanding feature - the importance attached during training to the so-called political studies, generally known in the listing of courses as Marxism-Leninism. For instance, in the sixth-year medical 
curriculum there are not less than 250 hours set aside for "political studies" as against, for example, 250 for histology and embriology, 213 for general surgery and 397 for anatomy.

In the first year of the medical course there are five customary subjects, plus philosophy and a foreign language. The same recurs in the second year. In the third year the Marxist-Leninism is expected to be presented by the clinical teachers themselves and they are instructed to find the Marxist philosophy to support their clinical evidence.

In November last a typical article in "The Medical Worker" called "The Vital Problem of Medical Education - The inculcation of a materialistic world outlook" contained this sentence: "The unanimous opinion of the Chairman of Examinations is that students now receive a more thorough training in the sphere of materialist humanist philosophy.

The following paragraphs from another edition of "The Medical Worker" give a vivid picture of the tackling of the will of the busy graduate. The article is called "The Political Training of Cadres" and it reads :

"There are 1,000 doctors and about 3,000 doctors' assistants, midwives, laboratory workers and technicians in the Lenin District of Moscow. In order to organise the propaganda of Marxist-Leninist knowledge among them and keep them informed on current political events, it was essential in the first place to form groups of agitators and propagandists. This required much patience and the ability to arouse interest in people for political work. The doctors, for example the senior specialists, referred to the mass of work they had on hand, or expressed doubt in their propagandising abilities. All this is now in the past. The majority of our senior doctors and their deputies are excellent agitators and propagandists".

Further on, the author says: "The lectures are given in the conference hall of the second municipal hospital. The premises are convenient and hold about 400 people... The majority of medical workers study independently the works of the classics of Marxist-Leninism ... including Pavlov".

Former Soviet physicians indicated that political indoctrination courses weighed heavily on their study schedules and were generally disliked for two main and significant reasons. As one woman physician expressed it, "If I wanted to know political disciplines excellently I would have to devote $75 \%$ of my time to them. Everybody struggled with these political courses. As much time as you devoted to them, you could not pass these examinations with excellent grades. How could you remember what Stalin said, and all these congresses! It was driving us crazy. In the streetcars you could see all the students trying to learn the history of the Party".

Another reason for disliking these studies was that political courses were considered more important than medical courses. Indeed physician after physician reported than failure to pass a political course or examination would have much more serious consequences than failing strategic medical subjects.

During 1961 a book was published called "Questions of Dialectical Materialism and Medicine". This illustrates the level and depth of thought given to the ideological basis of medicine.

A review of this book appeared in November in "The Medical Worker". Some quotations from this are indicative: "The book says that dialectics is a study of the fluidity and changeability of phenomena in the objective world and the reflec- 
tion of these processes in the mind of man. It speaks of the enrichment of the profession by technical means, chemical reactors, products of atomic radiation and the use of computators, all of which are grouped as 'cabinetic diagnostics', but 'in any achievements of medical technique... the main factor in medical practice is the thinking of the doctor. The perfection of this most important "weapon" of the medical profession is one of the most serious tasks of training medical cadres" ".

The review makes the point that an attempt has been made to illuminate concrete medical problems in the framework of dialectical materialism - for the first time.

The book deals with the Marxist-Leninist theory of laws and values governing the phenomena of the world, stressing the fact that with dialectical materialism they will fathom all knowledge and that they are entirely free of the "mystical".

In other words, their work is motivated by Pavlov, whose thesis is that man is responsive only to his environment and not to higher forces.

And finally, the editorial of the official organ of the Union, "The Medical Worker", on the 10 th of October 1961, stipulates that it is the duty of each man "to light in the heart of everybody the unextinguishable flame of the successful implementation of the struggle for fictory of Communism in our country".

Who are the men who keep this vast profession in line with the Revolution?

About $20 \%$ only of the profession belong to the Party, and they are the men who keep the profession in line.

The Party has always limited its membership, making it an achievement rather than merely a matter of willingness to join. Continued membership is contingent on serving the Party and submitting to its demands. The Party prefers to remain small and manageable, efficient, easily controllable.

Although $80 \%$ of our colleagues in the Soviet are not in the Party, Soviet philosophy, carried to its ultimate by continuing and massive indoctrination, as Harold Hillenbrand says, "cannot help but militate against and eventually destroy the practitioner-patient relation which is the essence of a sound health service".

Thus to recapitulate :-

The dentist under the Soviet system finds himself embedded in a larger profession which is completely controlled and directed by a small cadre of professionals within the Party. He is faced throughout his career with the requirement not to place service to the patient foremost, but service to the ideology of the State he serves. And to ensure that the requirements of the system are fully understood and accepted, he is subjected to an intense programme of indoctrination at every stage of his career right from his student days.

The authors believe it is a matter of urgency that we study and understand how all this has come about.

All these facts would only be of academic interest if that were all there were to it. There is much more to it than that. This is not merely another way of running a profession. It is an all-out compulsory transformation of a professional man into a $\operatorname{cog}$ of the machinery of world take-over for dialectical materialism. Vast numbers of men are having their lives and their motives completely re-directed, whether they want it or not, by this force - which is not content with having gained power in a few countries, but is reaching out for the world.

There is a new factor operating in the world today, and knowledge of it is 
essential for those who intend to be alive in the next decade. This new factor is ideology. In the free world many still baulk at that word, dismissing it as something meaning either Fascism or Communism, totalitarian aberrations which do not concern free men. This is precisely what Communists would have us believe, for they have discovered the power of an idea that is lived, as distinct from one which is conventionally believed, but to which only lip-service is given. Such an idea has to be big enough to inspire total dedication, and in this jet-shrunk age that means big enough to cover the world. That is ideology - an idea that is lived.

Communism, with its vision of a classless society and social justice, of being the inevitable next step in history, not just for one country but for the world, is such an idea. But it is born of bitterness, it builds on hate and has to rule by fear. It declares that the end justifies all means, and forgets that the means used determine the ends reached. Yet because it is an ideology, that is an idea lived with dedication by men trained to let it govern all thought and action, it is immensely powerful. Communists have actually gained control of nearly half the world in less than half a century.

Believing that ideology is the science of dealing with human nature and that it is designed to affect the whole world, we have naturally gone to study and take part in ideological actions at various strategic points.

The authors of this paper have gathered first-hand information at a refugee camp in West Berlin; in talks with Japanese who have escaped from labour camps in Russia; with German miners who first heard of moral re-armament as the alternative to Communism in the slave camps of Siberia; we have talked with a senior surgeon who was squeezed out of China and a senior surgeon at present in the Congo.

We have taken part in ideological action in Scandinavia, Germany, Holland, France, Switzerland, Italy, Cyprus, the West Indies, the United States and so on.

All this, coupled with the very obvious division and the ideological vacuum in the Western world, has borne in on us the urgency of the situation.

As far as our practice is concerned, far from it suffering, the reverse has proved to be true from both the business and the professional aspects. It has been our experience that when a man's personal success and personal security are put into second place so that he primarily lives to understand and bring an answer to the world ideological struggle, his own nature begins to alter profoundly.

The fear which was always in the background, attendant on failure to succeed and the strain in the background associated with the drive for personal success, no longer bear in with the same urgency, because they are replaced by a new motive.

A single-minded commitment to something much greater than ourselves and our own plans renders decisions at the chairside, in the office or about staff much less complicated.

Relating our professional lives in this way has dealt effectively with the sense of frustration which comes to us all when we get that deep sense of unease about the direction and speed of world events and do not know what we can do about it.

G. H. Leatherman writes in the International Dental Journal :

"It is becoming increasingly obvious that dentistry has come to a cross-road in the paths of its progress as a health profession. To the average dentist in practice, concerned mostly with personal problems, public health dentistry, dental welfare and service to the community are political slogans. There is a tendency for members of 
the profession today to look upon their privileges as the right to protect a vested interest, and there is the danger that as a result the profession may lose some of the preferential position it now holds. Great Britain has a comprehensive health service, but organised dentistry still has no practical plans, accepted both politically and economically, to take its proper place in the service. The leaders of the British Dental Association spend most of their time fighting for better terms. There is an annual expenditure of $£ 50,000,000$ mostly on a break-down or repair service... The public will not allow any Government to tolerate these conditions indefinitely".

One of the most senior and respected deans of dental schools was asked a few weeks ago for his comments on the modern dental student. His reply was "It depends what yardstick you are using. If you use the yardstick of intellectual ability and technical ability, they are the finest we have ever had. If, however, you use a moral or ethical yardstick, they are the worst we have ever had. The vast majority are simply in dentistry for what they can get out of it".

For many the examination of the impact of self-interest on professional life leads to the fear of getting mixed up in religion or politics. But the authors of this paper are attempting to deal with something much more fundamental than the religion and politics which most people mean when they use these words. Modern man lives in a different world, governed by different rules. The issues are not primarily political, religious or economic. They are ideological and will be decided on the basis of which ideology deals most successfully with human nature.

The Soviets are forging ahead towards their tremendous vision by compulsion, coercion and education.

But according to Lenin's biographer, Deutscher, he admitted that Marxism had never dealt with human nature. He saw jealousy and lust for power grow among his comrades and lieutenants and that in spite of the Revolution there was no fundamental difference between the bureaucracy of the Bolsheviks and that of the Czarist regime.

Deutscher writes that Lenin on his death-bed said "I am, it seems, strongly guilty before the workers of Russia" because he had promised them something that could not be fulfilled.

For us to be merely anti-Soviet will lead us nowhere. And yet the way we live and the things we live for have failed to commend themselves either to the Soviets or to the countries emerging into freedom and nationhood.

The quotations from Leatherman and the Dean put their finger on the need for change in us and our profession. As we are at a cross-roads, why not pioneer something new and superior to both the Soviet materialism and Western materialism?

If we try and meet the crisis in an entirely dental framework, we will be treating symptoms and not causes, because the root of the trouble is in our natures and motives.

Where do we go from here and what do we need to do now? Well, first of all we need to take this question of ideology seriously.

And secondly we need to recognise that acceptance of an ideology clarifies many issues and provides a dynamic for effective action.

Thirdly, we need to recognise that the things which we shrink from in the Communist system are rooted in this materialism that bedevils both us and them.

And finally we need to decide to pay the price in a voluntary redirection of our 
personal motivation for an ideology which is superior to anything the Communist or non-Communist world has yet discovered. 